\title{
Non-linear relationship between industrial service offering and sales growth: The moderating role of network capabilities
}

\author{
Marko Kohtamäki ${ }^{\text {a,* }}$, Jukka Partanen ${ }^{\mathrm{b}}$, Vinit Parida ${ }^{\mathrm{c}}$, Joakim Wincent ${ }^{\mathrm{c}}$ \\ a University of Vaasa, Department of Management, Entrepreneurship and Innovation, Luleå University of Technology, PO Box 700, FI-65101 Vaasa, Finland \\ b Aalto University, School of Economics, PO Box 21250, 00076 Aalto, Finland \\ c Entrepreneurship and Innovation, Luleå University of Technology / University of Vaasa, Department of Management, SE-97187 Luleå, Sweden
}

\section{A R T I C L E I N F O}

\section{Article history:}

Received 26 August 2012

Received in revised form 1 July 2013

Accepted 9 July 2013

Available online $\mathrm{xxxx}$

\section{Keywords:}

Industrial service offering

Industrial service business

Network capabilities

Alliance capability

Firm sales performance

\begin{abstract}
A B S T R A C T
In an effort to approach the mixed findings regarding the relationship between a firm's industrial service offering and its performance, this study analyzes the impact of the industrial service offering on sales growth and the moderating role of network capabilities. The proposed research model is tested based on data from 91 Finnish manufacturing firms. Our results demonstrate a non-linear effect of the service offering on sales growth. We also find that network capabilities enhance the effect of the service offering on sales growth. For managers of manufacturing firms, the results imply that the active development of a comprehensive service offering should be implemented in conjunction with the development of organizational capabilities, such as network capabilities, to create value and promote improved performance.
\end{abstract}

(c) 2013 Elsevier Inc. All rights reserved.

\section{Introduction}

Industrial firms are striving both to complement their products with a set of value-added services and to re-position themselves as solution providers (Davies, Brady, \& Hobday, 2007; Helander \& Möller, 2008; Meier, Völker, \& Funke, 2011; Vargo, Maglio, \& Akaka, 2008). Increased customer demand (Oliva \& Kallenberg, 2003), competitive pressures (Anderson \& Narks, 1995; Gebauer \& Friedli, 2005; Uppenberg \& Strauss, 2010) and the pursuit of more stable revenues (Gebauer \& Fleisch, 2007; Oliva \& Kallenberg, 2003) operate as catalysts for this transformation. Therefore, several large product manufacturers, such as ABB, Caterpillar, KONE, Rolls-Royce and Wärtsilä, have increasingly adopted a service logic intended to offer benefits in terms of product, service or solution sales revenues and profitability (Oliva \& Kallenberg, 2003; Salonen, 2011).

Studies have proposed that industrial services provide additional revenues throughout the product life cycle and increase product sales to ensure success (Gebauer \& Fleisch, 2007; Oliva \& Kallenberg, 2003). Researchers such as Gebauer, Edvardsson, and Bjurko (2010) suggest that up to $50 \%$ of the revenue in product firms may be derived from services. However, the existing research is mostly qualitative or normative (Jacob \& Ulaga, 2008), providing modest and suggestive empirical

\footnotetext{
* Corresponding author. Tel.: + 35829449 8459; fax: + 35863248195

E-mail addresses: marko.kohtamaki@uwasa.fi (M. Kohtamäki), jukka.partanen@aalto.fi (J. Partanen), vinit.parida@ltu.se (V. Parida), joakim.wincent@ltu.se (J. Wincent).
}

evidence on the performance effects of a service strategy (Gebauer et al., 2012; Jacob \& Ulaga, 2008; Raddats \& Burton, 2011). More importantly, the evidence provided by existing studies is mixed in terms of the optimal performance effects of industrial services (Gebauer et al., 2012; Jacob \& Ulaga, 2008; Neu \& Brown, 2005). For instance, some early studies (Davies, 2004; Oliva \& Kallenberg, 2003) suggest a positive performance effect of industrial services; more recent studies, however, are less conclusive about the exact level of performance that industrial services generate and even suggest a negative influence at certain points (Neely, 2008) or a non-linear performance effect (Fang, Palmatier, \& Steenkamp, 2008). Overall, these conflicting accounts suggest that the relationship between industrial services and firm performance is far more complex than has been anticipated by previous empirical studies.

In an effort to advance our understanding of the relationship between a firm's service offering and its performance, we have concentrated on two specific contributions. First, we posit that the relationship between the service offering and sales growth is positive but can be non-linear, which would imply that performance effects arising from an expanded industrial service offering may only pay off after a certain point (Fang et al., 2008). Such a view has yet to be critically examined and may further explain why certain industrial firms are able to succeed with their service strategy. Second, the present study responds to calls for research to test the growth effect of an industrial service offering by proposing that network capabilities play a moderating role. The strategic capability literature (Jiang, Henneberg, \& Naudé, 2011; Long \& Vickers-Koch, 
1995; Wittmann, Hunt, \& Arnett, 2009) suggests that organizational capabilities may mediate the link between service strategy and financial performance (Gebauer, Edvardsson, Gustafsson, \& Witell, 2010; Kohtamäki, Partanen, \& Möller, 2013; Raddats \& Burton, 2011). Prior studies also acknowledge the importance of certain routines and processes for coordinating customer service interactions because value is often co-created in interactions between manufacturers and customers (Lockett, Johnson, Evans, \& Bastl, 2011; Lusch, Vargo, \& Tanniru, 2010; Möller, Rajala, \& Westerlund, 2008; Ramirez, 1999). Therefore, we suggest the role of network capabilities (e.g., the ability to manage, integrate, and learn from customer relationships) is a critical one, in that it enables value creation in service interactions (Nam \& Lee, 2010; Walter, Auer, \& Ritter, 2006).

In brief, this study responds to calls for research on the performance impact of industrial services (Fang et al., 2008; Gebauer et al., 2012) and the enabling effect of organizational capabilities. We test the positive but non-linear effect of the service offering on sales performance and, even more importantly, the moderating effect of network capabilities on the proposed link based on a sample of 91 industrial product manufacturing firms. Thus, this study increases our understanding of the critical role of network capabilities as a value-creating mechanism in the industrial service context.

\section{Theory and hypotheses}

Below, we review the literature related to our main constructs before detailing our hypotheses development, suggesting that service offering may be positively associated with sales performance (albeit in a non-linear form). In addition, we suggest that network capabilities moderate the proposed relationship. We first review and present an operational definition of the concept of the service offering and then turn to the origins and operationalizations of network capabilities found in the literature.

\subsection{The service offering in industrial firms}

The transformation from merely focusing on industrial products to more comprehensively delivering a service offering is an important trend in industrial firms (Gebauer, Edvardsson, \& Bjurko, 2010; Gebauer, Edvardsson, Gustafsson, et al., 2010; Gebauer, Fischer, \& Fleisch, 2010; Kowalkowski, Witell, \& Gustafsson, 2013; Matthyssens \& Vandenbempt, 2008). Industrial service researchers have written about the provision of a service and solution offering under related but different concepts, such as advanced services (Baines, Lightfoot, \& Smart, 2011; Oliva \& Kallenberg, 2003), solution and system integration (Davies, 2004; Davies, Brady, \& Hobday, 2006), and product-service systems (Baines, Lightfoot, Benedettini, \& Kay, 2009). Many studies refer to the transformation from industrial products to service or solution businesses by applying concepts such as servitization (Baines et al., 2009; Boyt \& Harvey, 1997; Gebauer, Edvardsson, \& Bjurko, 2010; Gebauer, Edvardsson, Gustafsson, et al., 2010; Gebauer, Fischer, et al., 2010; Wynstra, Van Weele, \& Weggemann, 2001), service transition (Antioco, Moenaert, Lindgreen, \& Wetzels, 2008; Fang et al., 2008) and service infusion (Gebauer, 2008; Löfberg, Witell, \& Gustafsson, 2010). Therefore, prior research presents a rather complex definition of what constitutes an industrial service offering. We propose that a service offering, or 'service provisions', can be viewed as a central dimension (Homburg, Fassnacht, \& Guenther, 2003) or a manifestation of an industrial service strategy (Gebauer et al., 2010: 106). Consistent with previous studies (e.g., Homburg et al., 2003), we view an emphasis on the sales and marketing of industrial services as integral to the concept of a service offering. Table 1 below synthesizes the important contributions of prior studies.

From the studies listed in Table 1, we can identify different classifications of industrial services. The first classification considers the product and process relatedness of services: a) product-related
Table 1

Dimensions of industrial services in prior studies.

\begin{tabular}{|c|c|}
\hline Author(s) & Service dimensions \\
\hline Mathieu (2001) & $\begin{array}{l}\text { 1) Product services } \\
\text { 2) Services as products } \\
\text { 3) Customer service }\end{array}$ \\
\hline $\begin{array}{l}\text { Cunningham and Roberts } \\
\text { (1974) }\end{array}$ & $\begin{array}{l}\text { 1) Convenience service activities } \\
\text { 2) Reliability service activities }\end{array}$ \\
\hline Morris and Davis (1992) & $\begin{array}{l}\text { 1) Pre-transaction services related to internal } \\
\text { operations } \\
\text { 2) Transaction services related to physical appearance } \\
\text { 3) Transaction services related to order status } \\
\text { 4) Transaction services related to order accuracy } \\
\text { 5) Post-transaction services related to start-up } \\
\text { 6) Post-transaction services related to problem } \\
\text { handling }\end{array}$ \\
\hline $\begin{array}{l}\text { LaLonde and Zinszer (1976); } \\
\text { Samli et al. (1992) }\end{array}$ & $\begin{array}{l}\text { 1) Pre-transaction or presale services (e.g., written } \\
\text { customer policy) } \\
\text { 2) Transaction services (e.g., order cycle time) } \\
\text { 3) Post-transaction or post-sale services (e.g., } \\
\text { maintenance) }\end{array}$ \\
\hline Oliva and Kallenberg (2003) & $\begin{array}{l}\text { 1) Basic installed base services } \\
\text { 2) Maintenance services } \\
\text { 3) Professional services } \\
\text { 4) Operational services }\end{array}$ \\
\hline $\begin{array}{l}\text { Gebauer, Edvardsson, } \\
\text { Gustafsson, et al. (2010) }\end{array}$ & $\begin{array}{l}\text { 1) Customer service } \\
\text { 2) Basic service for the installed base } \\
\text { 3) Maintenance service } \\
\text { 4) R\&D-oriented service } \\
\text { 5) Operational service }\end{array}$ \\
\hline Homburg et al. (2003) & $\begin{array}{l}\text { 1) Information and consulting services } \\
\text { 2) Services for training and further consulting } \\
\text { 3) Services in the business-related field } \\
\text { 4) Services for technical security and optimization } \\
\text { 5) Services supporting the process of cooperation }\end{array}$ \\
\hline $\begin{array}{l}\text { Meier et al. (2011); Tukker } \\
\quad(2004)\end{array}$ & $\begin{array}{l}\text { 1) Product-oriented: product-related advice and } \\
\text { consultancy } \\
\text { 2) User-oriented: product lease, product rental and } \\
\text { product pooling } \\
\text { 3) Result-oriented: activity management, pay per } \\
\text { service unit and functional results }\end{array}$ \\
\hline
\end{tabular}

services (e.g., installation), b) process-related services (e.g., the operation of customer processes) and c) service products per se (e.g., finance options) (Cunningham \& Roberts, 1974; Mathieu, 2001; Oliva \& Kallenberg, 2003). Another classification centers on the product life cycle (time dimension): 1) pre-transactional (e.g., R\&D), 2) transactional (e.g., customer seminars) and 3) post-transaction services (e.g., maintenance) (LaLonde \& Zinszer, 1976; Morris \& Davis, 1992; Samli, Jacobs, \& Wills, 1992). Some combinations of these dimensions appear to create an embedded base for most of the existing service classifications.

To develop an operationalization of the different views presented in previous literature, we initially considered six dimensions of the service offering: 1) maintenance services (Boyt \& Harvey, 1997; Gebauer, Edvardsson, and Bjurko (2010); Gebauer, Edvardsson, Gustafsson, et al., 2010; Gebauer, Fischer, et al., 2010; Homburg et al., 2003; Morris \& Davis, 1992; Oliva \& Kallenberg, 2003; Samli et al., 1992), 2) R\&D services (Gebauer, Edvardsson, \& Bjurko, 2010; Gebauer, Edvardsson, Gustafsson, et al., 2010; Gebauer, Fischer, et al., 2010; Homburg et al., 2003; Oliva \& Kallenberg, 2003), 3) customer services (Homburg et al., 2003; Morris \& Davis, 1992; Oliva \& Kallenberg, 2003; Samli et al., 1992), 4) finance and insurance services (Homburg et al., 2003; Samli et al., 1992), 5) performance services (Gebauer, Edvardsson, \& Bjurko, 2010; Gebauer, Edvardsson, Gustafsson, et al., 2010; Gebauer, Fischer, et al., 2010; Oliva \& Kallenberg, 2003), and 6) procurement services (Homburg et al., 2003). Subsequently, we identified 33 services within those dimensions. Based on the measurement purification processes (Anderson \& Gerbing, 1991; Byrne, 2001) that were employed for identifying an empirically sound operationalization (elaborated in the methodology section), we reduced the dimensions. In this study, we concentrate on the first three 
dimensions (i.e., maintenance services, R\&D services and customer services) because they most accurately reflect the nature of the service business in small and medium-sized product manufacturing firms. Small and medium-sized manufacturing firms often limit their service offering to maintenance, R\&D and customer services owing to a greater need for specialization and a lack of internal resources. Therefore, we define the concept of a service offering as the emphasis on the sales and marketing of 1) maintenance services, 2) R\&D services and 3) customer services (Table 2). As such, our classification should be justified by the nature of our population and data from small and medium-sized (SME) ${ }^{1}$ product manufacturing firms that are in the early stages of servitization. Table 2 highlights the final construct for service offering.

Although we acknowledge the contribution of previous approaches, our operational measurement is novel in comparison with prior studies (e.g., Homburg et al., 2003), which have primarily measured a service strategy by summing dichotomous service items and using the summed items as a proxy of the service strategy. Our measurement method is more fine-grained because it measures the promotional emphasis on each service separately and considers the shared variance between service dimensions as a reflection of the existence of an industrial service strategy.

\subsection{Network capabilities and value co-creation in industrial firms}

The existing research on industrial services has provided mixed results in terms of their performance effects. We argue that these mixed findings may result from the fact that the existing studies consider the industrial organization as a black box. According to the strategic capability view (Barney, Ketchen, \& Wright, 2011; Dyer \& Hatch, 2006; Madhok \& Tallman, 1998), capabilities are needed to create value from resources and competences (Long \& Vickers-Koch, 1995; Theoharakis, Sajtos, \& Hooley, 2009) for the realization of competitive advantage (Ulaga \& Reinartz, 2011).

The literature on network capabilities provides various labels and dimensions for conceptualizing the capability to manage, use and exploit inter-organizational relationships. The literature is consistent with the strategic capability view, which states that "resources are productive assets the firm owns; capabilities are what the firm can do" (Ulaga \& Reinartz, 2011: 6). Therefore, building on this general definition of capabilities, we consider that network capabilities enable the use of strategic resources for improved value creation (Kohtamäki et al., 2013; Theoharakis et al., 2009). To analyze the existing evidence on the antecedents, mechanisms and outcomes of network capabilities and related constructs, we systematically searched for studies from the top-tier (ABS3 and ABS4 level; Harvey, Kelly, Morris, \& Rowlinson, 2010) journals in marketing, strategic management, organization, entrepreneurship and small business, innovation and management using 20 network capability-related constructs that included "network capabilities", "network competence", "alliance capability", "alliance competence" and other related constructs. The literature search included an analysis of article abstracts and ultimately identified 42 relevant articles (Appendix 1). We continued a narrative literature search based on the reference lists of those 42 articles and then explored broader literature on inter-organizational networks and the interaction approach.

The search and review of the dimensionality of network capabilities demonstrated a vast variety of definitions and dimensions. To summarize the review results, we found three groups of dimensions and measures arising from the reviewed articles: 1) network management capability (e.g., coordination, management capability, control capability, alliance evaluation) (Schreiner, Kale, \& Corsten, 2009; Smirnova, Naudé, Henneberg, Mouzas, \& Kouchtch, 2011; Walter et al., 2006), 2) network integration capability (e.g., relational skills, bonding, customer linking capability, dialogue and structures) (Schreiner et al., 2009; Smirnova

\footnotetext{
${ }^{1}$ Based on the definition provided by the European Union, we view SMEs as having fewer than 250 employees and a turnover of less than $50 \mathrm{M}$ euros.
}

Table 2

The construct of service offering.

\begin{tabular}{ll}
\hline The dimension of the service offering & Services \\
\hline Maintenance services & Installation service \\
& Repair service \\
& Product upgrading service \\
& Maintenance \\
R\&D services & Research service \\
& Prototype design and development service \\
& Feasibility studies \\
& Problem analyses \\
& Analysis of a product's manufacturability \\
& Product demonstrations \\
& Customer seminars \\
Customer services & Technical user training \\
& Written information material \\
& Customer consulting and support by phone \\
\hline
\end{tabular}

et al., 2011; Walter et al., 2006) and 3) network learning capability (e.g., partner knowledge, internal communication, the alliance learning process, mechanisms, and relational capability as a learning process) (Kale, Singh, \& Arbor, 2007; Walter et al., 2006).

We adopted the view of Walter et al. (2006) and defined the construct of network capabilities as "a firm's ability to develop and utilize inter-organizational relationships" (Walter et al., 2006: 541). This view stems from the assumption that organizations vary in terms of their capability for nurturing and coordinating complex inter-organizational relationships to gain access to resources that are held by other organizations. According to Walter et al. (2006), network capabilities include four inter-related dimensions: coordination, relational skills, market knowledge and internal communication. We selected this construct because it integrates all core dimensions of network capabilities: network management capability (coordination), network integration capability (relational skills), and network learning capability (partner knowledge/internal communication). In the context of industrial services, we suggest that this operational view of network capabilities enables a manufacturing firm to align service relationships for the co-creation of value from the manufacturer's service activities (Smirnova et al., 2011). Network capabilities make the complex and trusting interactions needed for service value creation possible. Moreover, we consider network capabilities as a combination of dimensions, suggesting that no single dimension can provide the complete range of benefits of network capabilities (Kandemir, Attila, \& Cavusgil, 2006; Wales, Patel, Parida, \& Kreiser).

Although rarely referenced directly in the context of industrial services, the enabling effects of network capabilities have been demonstrated in prior studies on new product development, innovation and innovation success (Capaldo, 2007; Ritter \& Gemünden, 2004; Theoharakis et al., 2009), long-term orientation (Jiang et al., 2011), joint alliance success (Lambe, Spekman, \& Hunt, 2002), partnership performance (Kohtamäki et al., 2013; Phan, Styles, \& Patterson, 2005), alliance financial performance (Wittmann et al., 2009), customer value (Kim \& Kim, 2009), customer satisfaction (Kim \& Kim, 2009; Orr, Bush, \& Vorhies, 2011), customer loyalty (Kim \& Kim, 2009), customer equity (Kim \& Kim, 2009), network status (Schreiner et al., 2009), business performance (Smirnova et al., 2011), the abnormal stock returns of companies (Kale, Dyer, \& Singh, 2002; Swaminathan \& Moorman, 2009), and financial performance (Orr et al., 2011; Wales et al.). However, there is relatively little evidence regarding any specific outcome because only a few empirical studies can be found for each outcome. Nevertheless, we believe this background suggests that the construct may be valuable in understanding the successful service offering in manufacturing firms.

Overall, the empirical evidence on the role of network capabilities in the context of industrial services is almost non-existent, despite the fact that the interaction between these phenomena is particularly relevant (Gebauer et al., 2012; Theoharakis et al., 2009). Moreover, many of the existing empirical studies use somewhat weak proxies for network 
capabilities, such as alliance experience or the existence of alliance functions. This fact establishes a sound rationale for further exploring the mechanisms and outcomes of network capabilities in the context of industrial services.

\subsection{Hypotheses development}

\subsubsection{The influence of the industrial service offering on sales growth}

Prior studies have suggested that providing industrial services offers more stable revenue than products because services generate revenue throughout the product life cycle and also in periods of economic recession when product sales may suffer (Gebauer, Edvardsson, \& Bjurko, 2010; Gebauer, Edvardsson, Gustafsson, et al., 2010; Gebauer, Fischer, et al., 2010; Oliva \& Kallenberg, 2003). Promoting a service offering means a firm actively marketing its service offering to customers, encouraging customers to become better informed about the manufacturer's willingness to create customer value through services that, together with products, can be bundled into integrated solutions that create value throughout the product life cycle.

Recent studies reveal that the relationship between industrial services and firm performance is far from simple, and it should be noted that the limited existing empirical research provides mixed evidence in terms of the service-firm performance link (Gebauer et al., 2012; Jacob \& Ulaga, 2008; Neu \& Brown, 2005). Hence, why studies call for further research on the performance effects of services (Gebauer et al., 2012: Fang et al., 2008). Most existing studies consider the impact of industrial services on profit performance (Gebauer et al., 2012) or examine the effect of industrial services on a firm's market value (Fang et al., 2008; Visnjic, Neely, \& Wiengarten, 2012). It is an approach that has been criticized because such measures can be considered quite distal performance measures compared to sales. According to our search and review, the research of Visnjic et al. (2012) is one of the rare studies that demonstrates the effect of service investments on a firm's sales growth; however, the measure applied to services was slightly more general than that applied in this study. Moreover, prior research seems to provide results that conflict (Neely, 2008) with the positive performance effect of industrial services (Oliva \& Kallenberg, 2003). More recent studies suggest negative (Neely, 2008) or non-linear (Fang et al., 2008) performance effects suggesting that the industrial services-firm performance link is far more complex than has been suggested in prior studies (Davies, 2004; Fang et al., 2008; Gebauer et al., 2012).

In this study, we propose that the performance impact of industrial services may be non-linear, in contrast to the linear relationship proposed previously (Gebauer et al., 2012). We believe that our literature review establishes that this view merits more attention. Fang et al. (2008: 1) consider that "the impact of a manufacturing firm's transition to services on firm value is relatively flat or even negative until the firm reaches a critical mass of service sales (20\%-30\%), after which point they have an increasingly positive effect." Fang et al. (2008) go on to argue that the effect of a service strategy on a firm's value is non-linear because the firm's service offering needs to be extensive enough to achieve the degree of market visibility required to have an impact on the firm's market value. However, the link between service offering and firm performance demands more attention because the results of Fang et al. (2008) are based on a secondary aggregated measurement of the service ratio capturing limited service offers in US manufacturing firms. In comparison, we apply a more fine-grained firm-level measurement for the service offering and study its effect on firm sales growth. As only the previously presented study has found a non-linear effect, we believe our study can provide valuable empirical evidence of such a relationship.

First, in a manufacturing industry context, a broader service offering constitutes a complex and more integrated bundle of services and products that is more valuable than individual add-on services, or separate products, representing an opportunity for greater sales growth (Meier et al., 2011). This suggests that individual add-on services (which would be the case in low and moderate levels of service offering) is equal to a low value service offering, whereas a high value service offering reflect a complex bundle of services and products sold as integrated solutions. As Davies (2004: 727) confirms, "services are combined with products to provide high-value 'integrated solutions' that address a customer's business or operational needs." This argument was extended by Brady, Davies, and Gann (2005: 360), who argued that offering integrated solutions produces "unique combinations of products and services that address a customer's specific business problems." Nevertheless, to encourage a positive perception of these valuable integrated solutions among customers, a strong service portfolio (from intermediate to high levels) is required. This implies a non-linear relationship between the service offering and sales performance is expected, as narrow or moderate range of add-on services are likely to be insufficient to generate a perception of highly valuable integrated solutions among the customer base. For instance, in the construction equipment industry, a weak add-on service offering, such as one comprising just product warranty or product demonstrations, is most unlikely to generate the level of sales growth of the products that offering total-care solutions, such as guaranteed availability for the duration of the contract would. In such cases, a broader service offering can also support product differentiation, making the offered solutions more attractive to large customers like mining firms that require large operational plant fleets and value reduced risk of breakdowns and the associated downtime.

Second, the non-linear relationship between service offering and sales growth can emerge because industrial firms serve diverse customer segments with varied service needs and the consequent service demand. For instance, customer segments with low expectations, because of using products with very little service needs, demand less and prefer lower overall prices for products and services, and hence favor free of charge service provision (Lovelock \& Wirtz, 2007). These segments may rely on other cost-efficient third-party service providers or may not require such services at all (Davies, 2004). In these instances of low or moderate levels of service demand, services generate very little if any revenue at all, and cannot have any significant impact on sales growth in the manufacturing firm. In contrast, in segments with higher expectations, where customers demand for operational services or turnkey solutions, they may be willing to pay for a broader range. In these cases, customers may choose to focus solely on their core competencies, and consequently outsource several non-core services (Davies, 2004; Windahl \& Lakemond, 2010). Moreover, customer segments marked by high expectations often aim to avoid transaction costs and opt for the convenience of buying services from a single supplier (Moore, 1995). This means that low to moderate levels of service offering is not enough to enhance sales growth. Following this logic, customer segments marked by high expectations might generate significant revenues, where their low expectation counterparts might not generate any revenues for a manufacturing firm.

To the background of the above arguments and given the mixed findings on the industrial service-performance relationship referenced above (Gebauer et al., 2012; Jacob \& Ulaga, 2008; Neu \& Brown, 2005), we argue that the effect of industrial services on growth is non-linear as low and moderate levels of service offering is not always certain to have significant impact on sales growth, but the presence of a very strong or superior service offering is likely to exert a positive effect on sales growth. Our reasoning for the non-linear effect was two-fold: 1) to sell bundles of services and products as integrated solutions, the level of service offering needs to be strong to create value that cannot be provided by individual add-on services; 2 ) customer segments with lower expectations request services without charge or buy services from the cheapest provider, whereas the customer segments with higher expectations demand ease of use and turnkey solutions and are willing to pay for valuable services. Thus, building on these two mechanisms, we expect industrial services to have a non-linear effect on the sales growth of firms. The performance effect requires medium to high levels of activeness in delivering the service offering to have a significant effect on sales growth, whereas a low to medium level of service offering will have next to no significant effect on sales growth. 
H1. A manufacturing firm's service offering exhibits a non-linear relationship with its sales growth.

\subsubsection{The moderating role of network capabilities}

Prior studies often consider service organizations as a 'black box' calling for research on structures and capabilities that moderate the performance impact of industrial services (Gebauer, Edvardsson, and Bjurko, 2010; Gebauer, Edvardsson, Gustafsson, et al., 2010; Gebauer, Fischer, et al., 2010; Raddats \& Burton, 2011). This study builds on the strategic capability view suggesting that service capabilities, such as network capabilities, play a central role in facilitating the creation of value from industrial service interactions (Baraldi, Gregori, \& Perna, 2011; Gebauer et al., 2012; Theoharakis et al., 2009).

Central argument in our approach is that a broader service offering increases the complexity of exchange processes and establishes a requirement for collaborative capabilities (Windahl \& Lakemond, 2006). In case of simple add-on services, from low to moderate levels of service offering, where service or solution exchanges are relatively straightforward, the exchange processes can be managed without significant levels of network capabilities. From moderate to high levels of industrial service offering, where services and products are often bundled to offer integrated solutions, exchange complexity increases. Thus, from moderate to high levels of service offering and exchange complexity, customer relationship management requires network capabilities (Antioco, Moenaert, Lindgreen, et al., 2008; Antioco, Moenaert, Feinberg, \& Wetzels, 2008; Berghman, Matthyssens, \& Vandenbempt, 2006; Kohtamäki et al., 2013). Prior studies have suggested that value co-creation in complex service interactions requires the active involvement of both the supplier and the customer (Grönroos, 2011). For instance, Kohtamäki et al. (2013) found that complex relational exchanges require relational forms of social capital, suggesting a need to develop relational capabilities for effective cooperation. Raddats (2011) offered evidence that relational resources enable industrial service differentiation providing opportunities for firm performance. Berghman et al. (2006) demonstrated that network competencies are important for customer value creation, whereas Möller and Törrönen (2003) considered network capabilities to be essential when partners create value from suppliers' offerings. Helander and Möller (2007) established that broadly-scoped service exchanges require far-reaching cooperation between the system supplier and customer. Theoharakis et al. (2009) evidenced that partnering capabilities improved organizational innovativeness, improving customer performance and, subsequently, the manufacturing firm's financial performance. Ritter and Gemünden (2003) demonstrated that network competence is needed for effective relational exploitation to generate and absorb the relational knowledge that a supplier can utilize to enhance innovation success. Finally, Raddats and Easingwood (2010) suggested the increasing importance of relational capabilities when the complexity of exchanges increases. Building on the existing literature, our argument is that network capabilities enable value co-production of service and solution offering and value co-creation of customer's experience. From low to moderate levels of service offering, service exchanges are simple and can be managed without facilitation of network capabilities, but from moderate to high levels, where complexity of exchanges increases, network capabilities are needed.

Moreover, network capabilities are particularly important in effective adjustment of the supplier's offering to provide customer solutions without vast transaction costs (Helander \& Möller, 2007). Where the customer segments of lower expectations request simple add-on services, use self-service or buy services from a third-party service supplier, service exchanges can be coordinated as arm's length market relationship, where there is no need for significant levels of network capability. Instead in those customer segments, where customers expect customized turnkey solutions, suppliers need network capabilities to facilitate effective service, or solution exchanges. Hence, manufacturing firms that lack necessary relational routines would struggle to adjust their offering to customer requirements and most importantly provide customized integrated solutions (Ramirez, 1999). Lack of network capabilities in higher levels of service offering would be likely to result to longer lead-times, quality problems, and an unsatisfactory customer experience (Theoharakis et al., 2009). Thus, firms offering a few or a moderate level of service offering to customer segments of lower expectations may not be in need of network capabilities, whereas those firms that offer complex integrated solutions to customer segments of higher expectations, need for network capabilities (Brady et al., 2005; Davies et al., 2007; Windahl \& Lakemond, 2010). Thus, from low to moderate levels of firm's service offering, where customer expectations are relatively straight forward, network capabilities are not needed, but from moderate to high levels of a service offering, where complex integrated solutions are delivered to respond to higher expectations of customers, network capabilities positively moderate the effect of industrial service offering on the sales growth of a firm.

Our construct for network capabilities reflects the shared variance of dimensions that capture network coordination, relational skills, partner knowledge and internal communication (Walter et al., 2006). As a dimension of network capability, network coordination facilitates knowledge sharing that reduces knowledge asymmetries, enabling the manufacturer to ascertain the needs of customers and influence their value experience, loyalty and commitment. From the lower to moderate levels of offerings, where the service exchanges are simple, knowledge asymmetries are smaller, and less need exists for the network coordination. From moderate to high levels of service offering, where exchanges become complex, a need exist for network coordination, to facilitate effective exchanges of services and integrated solutions. Furthermore, relational skills allow a manufacturer to develop close relationships with customers and better understand their requirements. As an alternative to arm's-length market relationships, relational skills enable a manufacturing firm to engage customers in an open dialogue (Ballantyne, 2004; Leek \& Christodoulides, 2012; Paulraj, Lado, \& Chen, 2008) and increase trust (Jiang et al., 2011), commitment (Schreiner et al., 2009; Wittmann et al., 2009) and loyalty (Kim \& Kim, 2009; Theoharakis et al., 2009); all factors that are critical to customer value creation particularly in complex contexts, where service offering are bundled with products to create integrated solutions (Kohtamäki et al., 2013; Phan et al., 2005). Thus, relational skills are of importance from moderate to high levels of service offering, where service and solution exchanges require relational skills. Finally, effective service value creation requires the ability to absorb knowledge regarding the needs and expectations of existing customers (Ritter \& Gemünden, 2003). Capacity to absorb knowledge is particularly important in complex service interactions, from intermediate to high levels of service offering, and in customer segments of high expectations, where solution integration requires (Walter et al., 2006) partner knowledge that can be absorbed and communicated within the manufacturer's organization to stimulate customer learning and innovation (Kale et al., 2007; Walter et al., 2006). Hence, partner knowledge and internal communication play an important role in facilitation of knowledge absorption to enable coproduction of service and solution offering and to enhance value co-creation of customer's experience. All in all, dimensions of network capabilities play an important role in facilitation of valueco-production and experience co-creation from moderate to high levels of manufacturer's service offering, where exchanges are complex and much adjustment in customer interactions are needed.

In summary, to co-produce service and solution offering, and to cocreate value for improved sales revenues, a manufacturer needs network capabilities 1) to facilitate offering of highly complex services and products as integrated solutions and 2) to serve customers segments of high expectations to co-design and integrate service offering and resources (Ballantyne, Williams, \& Aitken, 2011; Lusch et al., 2010), and to ensure that its offering corresponds to customer needs (Ford, 2011; Payne, 
Storbacka, \& Frow, 2008). Thus, from low to moderate levels, where firm's service offering and resulting service exchanges are simple and customer expectations modest, network capabilities do not have any significant effect on firm-level sales, but from moderate to high levels, where firm's service offering bundles with products to complex and integrated solutions, and where customer expectations increase, firm needs network capabilities to co-create value and generate sales revenues.

H2. Network capabilities positively moderate the non-linear relationship between the service offering of a manufacturing firm and its sales growth.

\section{Methods}

\subsection{Data collection, response pattern and respondents}

Detailed data are needed to analyze the influence of service offering on service sales performance and firm sales growth because no public database provides such knowledge. Thus, we collected survey data from a population in the machine and equipment manufacturing industry (SIC 28) in Finland. Our sample consists of all machine and equipment manufacturing firms that are liable to pay the value-added tax and that employ 20 or more employees. The final sample included 404 firms. The survey data were collected during January and February 2010. These data reflect the existing situation in terms of service offering, service performance and network capabilities. Because the main dependent variable measured sales growth (percentage of revenue change) during periods of economic recession, we measured the objective sales growth from January 2008 to December 2011 (the change from 2008 to 2011). This measurement aligns the survey data collection nicely with the sales growth effect because the survey data were measured almost exactly in the middle of the sales growth period, which was measured as a four-year average change in sales revenue (20082011) covering the economic volatility that occurred in Europe and in Finland during 2008-2011.

We collected data through the application of a web-based questionnaire. We particularly targeted manufacturing firms that provided industrial services as part of their total offering. Before sending the questionnaires, we contacted the targeted firms by phone to request their participation in this study. When preparing for the data collection, we made approximately 2000 calls to reach selected firms and to motivate the key respondents. In addition, during the data collection, two reminders were sent. We received 122 firm responses, of which we excluded five questionnaires that were incomplete and two cases of outliers based on the interpretation of scree-plot images (Tabachnick \& Fidell, 2007). In addition, we removed 24 cases for which the financial data were not available. The final data set with the sales growth variable from 2008 to 2011 included 91 firm cases with a satisfactory response rate of 23\%; after accounting for refusals (75), we obtained a final response rate of $28 \%$. The response rate that resulted from the vast data collection efforts can be considered satisfactory in comparison to similar management surveys (Baruch, 1999).

Consistent with the industry population, most of the respondent firms were medium-sized, produced an average annual turnover of 72.4 million euros, employed an average staff of 292 employees, and had a profit margin of $2.42 \%$, a current ratio of 2.07 and, on average, 32 patents. We can conclude that the respondent firms and the industry as a whole are at an early stage of transformation toward a servicedominant business model because the average value for the service share of revenue was approximately $16 \%$. Moreover, products generated $64 \%$ and subcontracting generated $19 \%$ of the revenues of the industrial firms. Thus, our sample product manufacturing firms are in their early stages of service transformation.

Our survey was addressed to the managers (key respondents) who were responsible for the service business development. The respondents were selected by calling firms and speaking with their managing directors. Of the key respondents, $71 \%$ operated as managing directors,
$20 \%$ as sales managers, $6 \%$ as business developers, $2 \%$ as R\&D managers and $1 \%$ as production managers. Despite our high response rate, we analyzed the data for non-respondent bias. During this analysis, the respondent firms were compared to the entire population of actual respondents using three variables: revenue, profit and balance sheet value. Because the differences between the data and the research population were not statistically significant, we concluded that the data were free from non-respondent bias and were generalizable to the research population of product manufacturing firms.

\subsection{Analysis method and measurements}

The constructs and items were adapted from prior studies and then translated and back-translated (English-Finnish-English) by another researcher to confirm translation equivalence (Brislin, 1970). In addition, prior to the data collection, three manufacturing firm managers evaluated the questionnaire and provided us with valuable feedback.

We defined service offering as the emphasis that a manufacturer places on the marketing of a particular service to reflect the existence of industrial service strategies in product manufacturing firms. Building on the work of previous scholars (Gebauer, Edvardsson, \& Bjurko, 2010; Gebauer, Edvardsson, Gustafsson, et al., 2010; Gebauer, Fischer, et al., 2010; Homburg et al., 2003; Homburg, Hoyer, and Fassnacht 2002), we chose to conduct a service-specific assessment of how actively each service is offered to customers using a Likert scale $(0=$ not offered; $1=$ not actively at all; $7=$ very actively). In addition to the literature search and review, we received support from 23 interviews/ workshops at four case firms and from interviews with five academic experts to develop our service offering construct. We adapted the measures from prior studies, complemented with a few measures derived from interviews, and tested the content validity of both the construct and its dimensions prior to the data collection. In this pre-test, we applied the content validity index and asked nine experts in strategy and service marketing to evaluate whether each item corresponded to the definition of the dimension that it was intended to measure using a scale ranging from one to four ( $1=$ not relevant, $2=$ somewhat relevant, $3=$ quite relevant, $4=$ highly relevant) (Polit, Beck, \& Owen, 2007). We evaluated the validity of the construct using the content validity index (average I-CVI), with all dimensions topping the threshold of .8 (Davis, 1992; Polit et al., 2007). Following the data collection with the final pre-validated questionnaire and 33 industrial services in six dimensions, we tested the dimensionality of the construct by applying the principal axis factoring and the oblique rotation method. In the factor analysis, all of the items loaded above .40 onto their main factors without significant side loadings $(<.40)$. As a result of the explorative factor analysis, we identified six dimensions, including maintenance services, R\&D services, product-information-sharing services, finance and insurance services, performance services, and procurement services. In comparison with the previous pre-validation, business services were separated into three dimensions: a) finance and insurance, b) performance and c) procurement services. These three dimensions were excluded from this analysis because their factor loading to the respective latent variable of the service offering was low $(<.5)$, which indicated that the factors poorly measured the latent phenomenon. We believe that this result stems from the data because the data include mostly small and medium-sized manufacturing firms in an early stage of service transformation. In these firms, some of the services were irrelevant. As a result, the final dimensions of the service offering construct were 1) maintenance services, 2) R\&D services and 3) product-information-sharing services. Following the application of these dimensions, the structural model demonstrated a good model fit: $\chi 2=50.35$, degree of freedom (d.f.) $=48, \mathrm{p}=.38, \chi 2 /$ d.f. $=1.05$, RMSEA $=.022$, GFI $=.93$, CFI $=.995$, and IFI $=.995$ (Bollen, 1989; Hu \& Bentler, 1999). Finally, the loadings for both the first- and second-order factors ranged from .57 to .91 . 
The current study defines network capabilities as the ability of an organization to develop and utilize inter-organizational relationships to gain access to various resources held by other organizations. We operationalized network capabilities as a four-dimensional construct with the sub-dimensions of coordination, relational skills, partner knowledge and internal communication. Network capabilities were measured by Likert-scale items ( $1=$ fully disagree, $7=$ fully agree). All items were adapted from the work of Walter et al. (2006). After the data collection and analysis, the dimension of market knowledge was transformed into partner knowledge to improve the face validity of the original network capabilities construct. These items were averaged into four parcels based on the results of principal axis factoring (Little, Cunningham, Shahar, \& Widaman, 2002) with the maximum likelihood rotation method to validate the four-dimensional structure. During the exploratory factor analysis, items that loaded below .40 onto their main factors and items with significant side loadings $(>.40)$ were removed. The remaining 14 items were factored into four parcels: "coordination", "relational skills", "partner knowledge" and "internal communication". Following the application of these dimensions, the structural model demonstrated a good model fit: $\chi 2=54.07$, degree of freedom $(\mathrm{df})=48$, $\mathrm{p}=.25, \quad \chi 2$ d.f. $=1.13, \quad$ RMSEA $=.035, \quad$ GFI $=.92, \quad$ CFI $=.99$, and IFI = .99 (Bollen, 1989; Hu \& Bentler, 1999). Finally, the loadings for both the first- and second-order factors ranged from .55 to .90 .

Sales growth was assessed using an objective measure as the average change in firm sales revenues from 2008 until the end of 2011. Our measurement approach was justified by the timing of the survey data collection because the survey data were collected in the middle of the growth period, at the beginning of 2010. An average measure from multiple years provides stability in terms of the measurement.

We controlled for seven effects of different variables on the sales growth of firms. We controlled for the effect of the product business on firm sales growth. As such, we wanted to exclude the direct effect of product revenues to study the effects of service offering on firm sales growth. Product performance was measured as the share of product sales of firm revenue (Antioco, Moenaert, Feinberg, et al., 2008; Antioco, Moenaert, Lindgreen, et al., 2008; Carbonell, RodríguezEscudero, \& Pujari, 2009). Furthermore, we controlled for the effect of the breadth of the customer base, which measures the number of customers. The breadth of the customer base provided an additional indicator of a firm's business model. A low number of customers reflect a subcontracting business model with a high dependency on a smaller number of existing customers, whereas a large number of customers would indicate a product business model and a lower dependency on any single customer. Subsequently, we controlled for the impact of the number of patents as a measure of firm-level innovativeness. In addition, we controlled the results for the number of employees (2010). However, we dropped the measure from the final research models due to its extremely high correlation with some studied variables. However, the number of employees had no significant impact on the effects of other variables or on the research model in general. In addition to these control variables, we controlled for the direct effect of network capabilities.

Finally, to avoid potential common method variance, we applied different controls and tests during the data collection and analysis (Podsakoff, MacKenzie, Lee, \& Podsakoff, 2003). During the data collection, we used various response formats and ensured the brevity of the questionnaire. For instance, service offering and network capabilities were measured using Likert-scale variables, whereas service and product performance were measured as a share of revenue. Most importantly, our main dependent variable, firm sales growth, was measured using an objective measure. However, in the analysis, we tested the data by applying the one-factor test proposed by Harman (1967; Podsakoff \& Organ, 1986). In the one-factor test, the first factor accounted for only $19.86 \%$ of the total variance in the factor matrix. Some researchers suggest that common method variance does not generate a serious threat to the interpretation of results, even if the first factor accounts for as much as $50 \%$ of the total variance (Rönkkö \& Ylitalo, 2011). Thus, the test results suggest that the data are satisfactorily free of common method variance.

\section{Results}

In the following paragraphs, we begin our analysis by presenting a correlation matrix of the constructs that are included in this study and then continue the analysis by presenting the regression models. Subsequently, we present the results of the structural model and interpret the plotted results. Table 3 presents the correlations between the given constructs and control variables and demonstrates that the highest correlation between the independent variables is moderately low at .35. Despite the moderate correlations, we decided to test the data for multicollinearity using a variance inflation factor (VIF) with a threshold of 10. Values for all of the constructs and models remain below 3.30, suggesting that the model is free from multicollinearity. Table 3 also presents the mean values and standard deviations of the study constructs.

We applied the Stata 12 software program and ordinary least squares regression and the adoption of mean-centered constructs to test our hypotheses (Aiken \& West, 1991; Gefen, Straub, \& Boudreau, 2000). Table 4 presents the results of the five studied models. The first model tests the effects of control variables, whereas the second model adds the main effects. The third model enters the non-linear squared term of the service offering. The fourth model adds the linear interaction, whereas the fifth model enters the non-linear interaction into the model and tests the moderating role of network capabilities on the non-linear effect of the service offering on sales growth. We present plotted results to enable an interpretation of the marginal effects.

We controlled for the effects of five control variables on firm sales growth, which are presented in Model 1 . The number of patents has no statistically significant effect on sales growth $(\beta=-.03$; n.s.). A similar result holds for the breadth of the customer base: the effect is low and non-significant ( $\beta=-.03$; n.s.). In contrast, the effect of product performance is positive but statistically non-significant $(\beta=.18$; $p \leq .05)$. Finally, the effect of slack resources is non-significant ( $\beta=-.13$; n.s.). Model 1 explains $4 \%$ of the variation in sales growth.

Model 2 enters the direct effects of the independent variables, service offering and network capabilities on sales growth. In this analysis, service offering demonstrates a significant positive impact $(\beta=.34 ; \mathrm{p} \leq .01)$ on sales growth, whereas the effect of network capabilities is non-significant $(\beta=.13$; n.s.). Model 2 contributes $19 \%$ to sales growth and differs statistically significantly from the baseline model $\left(\Delta R^{2}=0.15, F=3.21\right.$, d.f. $\left.=6,84, p<0.001\right)$.

Model 3 tests the non-linearity of service offering. Model 3 confirms the positive and statistically significant non-linear effect of service offering on sales growth $(\beta=.29 ; \mathrm{p} \leq .05)$. The plotted Fig. 1 demonstrates that the marginal effects become significant between the service offering levels 0.83 and 1.33 and continue to be significant until 4.33. Model 3 explains the variation of sales growth by $25 \%$, significantly improving model 2 where we tested the direct linear effect of service offering $\left(\Delta \mathrm{R}^{2}=0.06, \mathrm{~F}=3.88\right.$, d.f. $\left.=7,83, \mathrm{p}<0.05\right)$. The potential nonlinear effect of network capabilities was also tested but did not exist.

Model 4 added the linear interaction effect between service offering and network capabilities. The effect is significant ( $\beta=.27$; $\mathrm{p} \leq .05)$, as were the marginal effects (Brambor, Clark, \& Golder, 2006). To confirm the interaction, the results were plotted by the application of .5 intervals. The marginal effects (with a $95 \%$ confidence interval) become significant in between the service offering levels .33 and .83 and remain significant until the 4.33 level. Model 4 explains the variation of sales growth by $30 \%$, thus significantly improving model $2\left(\Delta R^{2}=0.05\right.$, $\mathrm{F}=4.38$, d.f. $=8,82, \mathrm{p}<0.05$ )

Model 5 adds the interaction between network capabilities and the squared service offering to study the moderating impact of network capabilities on the non-linear effect of a service offering. The hypothesized moderating effect of linear network capabilities on the non-linear effect of service offering on sales growth was significant $(\beta=.35 ; \mathrm{p} \leq .05)$. 
Table 3

Correlations among the constructs and control variables.

\begin{tabular}{|c|c|c|c|c|c|c|c|c|c|}
\hline & & Mean & SD & 1. & 2. & 3. & 4. & 5. & 6. \\
\hline 1. & Revenue growth & 2.40 & 24.74 & 1.00 & & & & & \\
\hline 2. & Service offering & 2.15 & 1.38 & $0.35^{*}$ & 1.00 & & & & \\
\hline 3. & Network capabilities & 4.82 & 0.82 & $0.22^{*}$ & $0.26^{*}$ & 1.00 & & & \\
\hline 4. & Number of patents & 32.04 & 119.58 & -0.02 & 0.04 & -0.19 & 1.00 & & \\
\hline 5. & Breadth of customer base & 1963.04 & 10529.99 & -0.02 & 0.09 & $0.23^{*}$ & 0.14 & 1.00 & \\
\hline 6. & Product performance & 64.62 & 29.40 & 0.15 & 0.10 & 0.10 & 0.07 & 0.04 & 1.00 \\
\hline 7. & Slack resources & 2.07 & 1.47 & -0.08 & 0.19 & -0.08 & -0.03 & -0.03 & $0.27^{*}$ \\
\hline
\end{tabular}

Notes: * indicates that $\mathrm{p}<0.05$, respectively (in two-tailed tests).

However, as argued in previous studies, it makes little sense to study the interaction effect based on beta coefficients (Brambor et al., 2006). Instead, the interaction effect should be studied by plotting the effect and testing the significance of marginal effects, which demonstrate the true significance of interactions (Brambor et al., 2006). The plotted marginal effects (.5 intervals in Fig. 2) suggest a positive moderating impact of network capabilities on the non-linear relationship between service offering and sales growth. The effect of a high level of network capabilities becomes significant between the service offering levels 0.83 and 1.33 and remains significant until 4.33. The effect of low network capabilities becomes significant between the service offering levels 2.33 and 2.83 and remains significant until the level of 4.33, as demonstrated in Fig. 2. At the intermediate level of network capabilities, the moderation effect is non-significant. Fig. 2 demonstrates that the effect of network capabilities on the relationship between service offering and sales growth is statistically significant from moderate to high levels of service offering. The final model 4 explains $34 \%$ of the variation of sales growth, improving model 3 significantly $\left(\Delta \mathrm{R}^{2}=0.04, \mathrm{~F}=4.61\right.$, d.f. $=9,81, \mathrm{p}<0.05)$. Fig. 2 confirms our $\mathrm{H}_{2}$.

To ascertain the validity of the research model, we tested whether the results were independent of the control variables. The model, coefficients and marginal effects remained significant after removing the controls, thus suggesting that the results were independent of our control variables.

\section{Discussion and implications}

\subsection{Theoretical contribution}

The existing industrial service business research presents relatively little evidence on the relationship between service offering policy and firm performance and particularly on the moderating role of the service organization (Gebauer et al., 2012). We argue that the relationship between industrial services and firm performance is non-linear and that the understanding of this association is enhanced by accounting for the moderating role of organizational capabilities, which facilitate service value creation.

This study extends the conversation on the performance impact of industrial services (Fang et al., 2008; Gebauer et al., 2012) and the enabling effect of organizational capabilities (Walter, Ritter, \& Gemüden, 2001; Walter et al., 2006) by demonstrating an important moderating effect of network capabilities on the link between service offering policy and the sales growth of firms. This study responds to the concluding remarks of Antioco, Moenaert, Feinberg, et al. (2008:352); Antioco, Moenaert, Lindgreen, et al., 2008, who suggested that relational aspects (e.g., trust, frequency of interaction, and the absence of mechanisms for resolving conflicts) could play important moderating roles between a service business and service volumes. Indeed, our study confirms that the existence of network capabilities enhances the positive non-linear influence that service offering activity can have on sales growth. More specifically, our contribution is twofold.

First, this study highlights the importance of service offering activity to firms' sales growth, demonstrating a non-linear relationship. We found only one previous study that also acknowledges similar nonlinear relationships (Fang et al., 2008); however, that study uses secondary data and so has limited potential to capture the level and effect of the service business on performance. Our results based on a multidimensional, firm-level measurement of industrial services, demonstrate that an emphasis on the service offering generates a positive and non-linear effect on sales growth. In particular, we find that the relationship between service offering and sales growth is only significant at moderate to high levels and not at lower levels of service offering. The

Table 4

The results of hierarchical regression analyses ${ }^{\mathrm{a}}$.

\begin{tabular}{|c|c|c|c|c|c|}
\hline $\begin{array}{l}\text { Dependent variable:Revenue growth } \\
\text { 2008-2011 }\end{array}$ & $\begin{array}{l}\text { Model } \\
1\end{array}$ & $\begin{array}{l}\text { Model } \\
2\end{array}$ & $\begin{array}{l}\text { Model } \\
3\end{array}$ & $\begin{array}{l}\text { Model } \\
4\end{array}$ & $\begin{array}{l}\text { Model } \\
5\end{array}$ \\
\hline \multicolumn{6}{|l|}{ Controlled effects } \\
\hline Number of patents & -.03 & -.01 & -.01 & -.03 & -.03 \\
\hline Breadth of customer base & -.03 & -.09 & -.07 & -.08 & -.05 \\
\hline Product performance & .18 & .15 & .18 & .14 & .16 \\
\hline Slack resources & -.13 & -.18 & -.12 & -.11 & -.15 \\
\hline \multicolumn{6}{|l|}{ Main effects } \\
\hline Service offering & & $.34^{* *}$ & .20 & .19 & .17 \\
\hline Network capabilities & & .13 & .11 & .11 & -.03 \\
\hline Service offering squared & & & $.29^{*}$ & .16 & .04 \\
\hline \multicolumn{6}{|l|}{ Moderation effects } \\
\hline Service offering $*$ Network capabilities & & & & $.27^{*}$ & .11 \\
\hline $\begin{array}{l}\text { Service offering squared } * \text { Network } \\
\text { capabilities }\end{array}$ & & & & & $.35^{*}$ \\
\hline$\Delta R 2$ & .04 & .15 & .06 & .05 & .04 \\
\hline$R^{2}$ & .04 & .19 & .25 & .30 & .34 \\
\hline Adjusted $R^{2}$ & -.01 & .13 & .18 & .23 & .27 \\
\hline$F$ & 0.49 & 3.21 & 3.88 & 4.38 & 4.61 \\
\hline
\end{tabular}

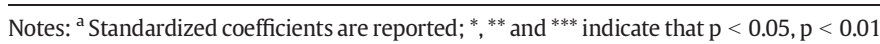
and $\mathrm{p}<0.001$, respectively (in two-tailed tests).

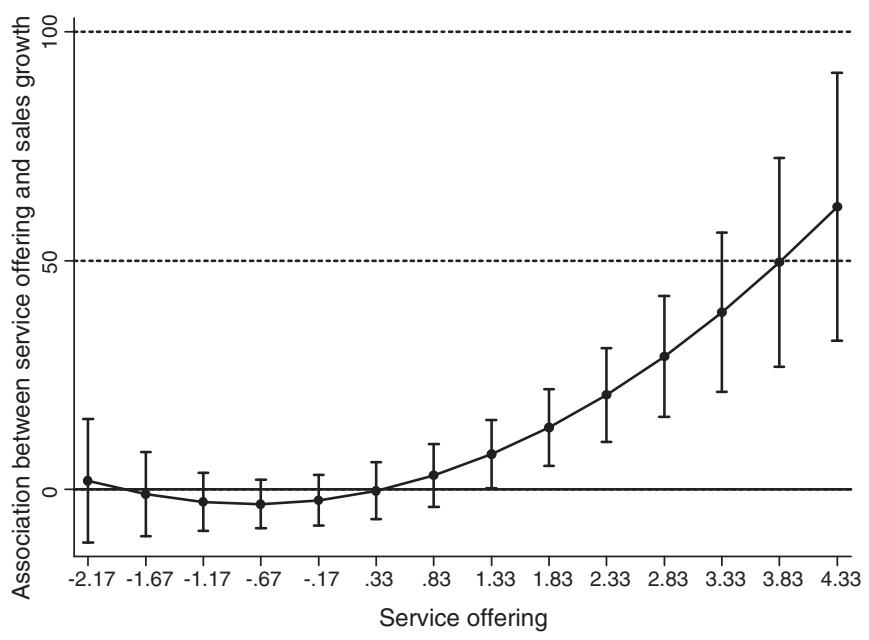

Fig. 1. The non-linear effect of service offering on sales growth (95\% confidence intervals). 


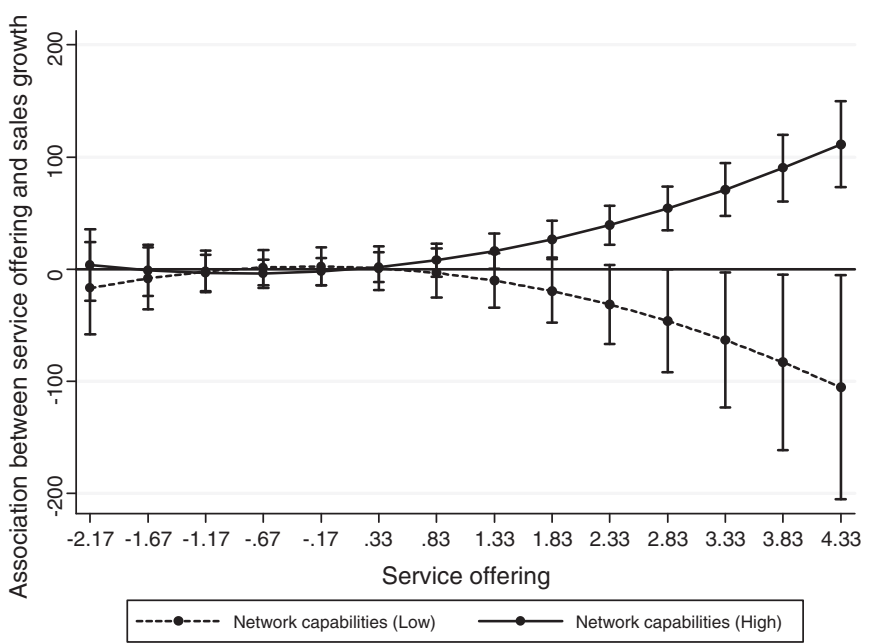

Fig. 2. The non-linear interaction of service offering and network capabilities on sales growth (95\% confidence intervals).

inflection point seems to be around 0.33 and 0.83 service offering levels and continue to be significant until 4.33, as illustrated in Fig. 1. This positive but non-linear relationship is motivated by two underlining reasons. First, non-linear relationship between service offering and firm sales growth may result from bundling strong service portfolio and products as integrated solutions to create value that cannot be provided by mere introduction of lower levels of add-on services. Second, we suggested that the non-linear relationship between service offering activity and firm sales growth may result from variety of customer segments to which services are being offered. Customer segments with lower expectations require services without charge or buy services from the cheapest provider, whereas the customer segments with higher expectations and needs necessitate turnkey solutions, but are also willing to compensate. Thus, our study makes a significant contribution by demonstrating and highlighting the positive but non-linear effect of a firm's industrial service offering on sales growth.

Second, this study contributes to the discussion on network, alliance and CRM capabilities of manufacturers and service providers (Kale et al., 2002; Ritter \& Gemünden, 2004; Smirnova et al., 2011; Walter et al., 2006) by considering how firms' manage, integrate and learn from network relationships. We demonstrate how network capabilities enable value creation from the activity of service offering by positively moderating the non-linear relationship of service offering and sales growth. In particular, we provide a novel insight regarding the moderating role of network capabilities. As depicted in Fig. 2, the importance of network capabilities for a manufacturing firm's increases at moderate to higher levels of service offering. The effect of a high level of network capabilities becomes significant between the service offering levels 0.83 and 1.33 and remains significant until 4.33. The effect of low network capabilities becomes significant between the service offering levels 2.33 and 2.83 and remains significant until the level of 4.33, as demonstrated in Fig. 2. We believe that this result is based on two underlying reasons. First, from moderate to high levels of service offering, services and products are often bundled to integrated solutions, which increases the complexity of exchanges and demands for network capabilities; Second, from moderate to high levels of service offering, customer segments of higher expectations demand for integrated solutions requiring co-production of service and solutions offering and cocreation of customer's experience. This result responds to scholars calling for studies on the factors that moderate the link between industrial services and firm performance (Gebauer, Edvardsson, and Bjurko, 2010; Gebauer, Edvardsson, Gustafsson, et al., 2010;
Gebauer, Fischer, et al., 2010; Kohtamäki et al., 2013; Raddats \& Burton, 2011). Thus, this study contributes by underlining the critical role of network capabilities for organizational competitiveness in the unique context of the industrial service business. In addition, we argue that our empirical setting is particularly suitable for testing the relevance of capabilities. The importance of organizational capabilities is highlighted by the pressures of difficult economic times, during which manufacturing firms and their customers must rapidly adapt to changing market conditions (Mintzberg \& Lampel, 1999). For instance, when product sales decrease during periods of economic recession, firms may need to engage in solution customization, which requires the development of interactive capabilities, such as network capabilities. Difficult economic conditions may highlight the importance of retaining existing customer relationships because new customers become increasingly difficult to reach. Under these conditions, managing, understanding and learning from existing customers may be critical for survival. Thus, the timing of our empirical study further highlights the role of network capabilities, which represents an additional contribution.

\subsection{Managerial contribution}

For managers of industrial firms, these results highlight the importance of the industrial service offering when combined with network capabilities enabling value creation from the service offering. To avoid the 'commoditization trap', industrial service firms may consider adding services as part of their total offering. However, according to the results of this study, the direct effects of service offering activity were positive but also non-linear, suggesting that firms should consider moving toward full service provision, developing a comprehensive service offering and value propositions so as to provide integrated solutions, to coproduce offerings and co-create customer's experience. Offering a few simple and disconnected services, such as installation and repair, may be necessary to respond to competition or sustain the performance of the industrial product business; but to generate additional sales through the service business, industrial firms need to offer a broader set of industrial services.

A comprehensive and consistent industrial service portfolio appears to have significant potential for value creation when combined with network capabilities. Thus, building on the results of this study, industrial firms should consider investments in network capabilities, such as network management, integration and learning capabilities (Kim \& Kim, 2009; Ritter \& Gemünden, 2003) for improved service value creation. The development of industrial service capabilities begins with a service offering policy (Antioco, Moenaert, Lindgreen, et al., 2008) and continues with an emphasis on organizational and relational capabilities. This study highlighted the importance of a strong service offering that can be bundled with products, to create integrated solutions, to serve customers of highest expectations. This finding also means that firms should decide on and implement a clear service strategy to achieve the desired performance outcomes. However, to co-produce service and solution offering and to co-create customer's experience to create financial value from a service offering requires the necessary network capabilities to be in place. Therefore, we would underline the importance of aligning organizational capabilities with the development of an industrial service strategy.

\subsection{Limitations and suggestions for further research}

As with every study, the current research is not without its limitations. We apply Finnish data from the product manufacturing industry. Because organizational capabilities, such as network capabilities, are culturally related, further evidence from other cultural contexts is required. In addition, evidence from more dynamic industries, such as high technology, would be interesting because it would provide a varying perspective of the role of the service 
business and the required capabilities. Because we primarily obtained results from small and medium-sized firms, the interpretation of the results must be limited to this specific context. However, we also consider this aspect of the research to represent one of the strong contributions of this study. It has been argued that, when studying new relations (exploratory study), such as in this case, it is advisable to focus on a limited context to control contingencies. According to Westerberg, Singh, and Häckner (1997), such a focus would make the data less vulnerable to the effects of uncontrolled variables because sample firms are from a common environment. Nevertheless, further evidence from large multinational firms would be useful. Large multinational firms can provide richer data on industrial service business models and a broader spectrum of network management practices.

The current study considers the service offering of a firm to be a reflection of its industrial service strategy. Future research could consider how to improve the measurement of an industrial service strategy. However, we believe that our measurement method is more finegrained than the methods used in prior studies because it measures the degree of activeness in offering services. However, further validation of our proposed measurement method should be undertaken. In addition, future industrial service studies should use both quantitative and qualitative methods to examine the organizational factors that affect the relationship between service strategy and performance. Moreover, although the present study found evidence of the non-linear relationship between an industrial service offering and sales performance and identified the positive moderating role of network capabilities, more evidence is needed on the nature of the industrial serviceperformance link and potential moderating constructs. Finally, we believe that network capabilities constitute important organizational capabilities that explain organizational success and survival. The current methods used to measure the relevant dimensions, such as network management, integration, and learning, require further development. Thus, we would encourage further development of the network capabilities construct and its measurement. Organizational network research can still contribute a great deal to establishing the importance and effects of network capabilities in combination with other organizational capabilities, and how they align with solution, service, and customization strategies.

\section{Conclusion}

The current study contributes to the literature by presenting evidence on the positive but non-linear effect of a firm's service offering on its sales performance and the positive moderating role of network capabilities. It appears that network capabilities enable the service offering to exert a positive non-linear effect on sales growth, suggesting an increased emphasis on the service offering and the necessary organizational capabilities to co-produce service and solution offering and to co-create customer's experience. Firms should consider network capabilities when searching for appropriate industrial service capabilities and consider their service offering in conjunction with network capabilities to be a potentially productive strategic resource combination.

\section{Acknowledgments}

This paper is a product of the SYSTEMI and FUTIS (Future of Industrial Services) research projects. The financial support of the Finnish Funding Agency for Technology and Innovation (Tekes), FIMECC and the companies involved in these projects is gratefully acknowledged. We would also like to acknowledge the support from the Faste Laboratory, a VINNOVA Excellence Center for Functional Product Innovation at Luleå University of Technology, Sweden.
Appendix 1. Articles found in different journal categories (based on ABS ranking)

\begin{tabular}{lllll}
\hline Journals & $\begin{array}{l}\text { Number of } \\
\text { articles found } \\
\text { based on } \\
\text { abstract search }\end{array}$ & $\begin{array}{l}\text { Number of } \\
\text { articles found } \\
\text { based on title } \\
\text { search }\end{array}$ & $\begin{array}{l}\text { Deleted } \\
\text { based on } \\
\text { abstract } \\
\text { review }\end{array}$ & $\begin{array}{l}\text { Number of } \\
\text { articles } \\
\text { selected for the } \\
\text { final review }\end{array}$ \\
\hline $\begin{array}{l}\text { Marketing } \\
\text { Organization }\end{array}$ & 20 & 10 & 1 & 19 \\
$\quad 2$ & 0 & 2 & 0 \\
$\quad 11$ & 4 & 0 & 11 \\
$\quad \begin{array}{l}\text { Strategic } \\
\text { management }\end{array}$ & 9 & 4 & 5 & 4 \\
$\begin{array}{l}\text { Innovation } \\
\text { Operations }\end{array}$ & 3 & 0 & 1 & 2 \\
$\quad 5$ & 0 & 4 & 1 \\
$\quad$ management & & 0 & 4 & 5 \\
$\quad$ Summary & 59 & 18 & 17 & 42 \\
\hline
\end{tabular}

\section{Appendix 2. Constructs and measurement items}

Constructs and Items (All measured on 7-point Likert scales, except the number of personnel and current ratio)

Service offering

How actively do you offer a particular service to your customer base ( select $0=$ if you do not offer the service at all, $1=$ not active at all, $7=$ very active)

Maintenance services

Installation service (Activeness in offering the service)

Repair service (Activeness in offering the service)

Product upgrading service (Activeness in offering the service)

Maintenance (Activeness in offering the service)

R\&D service offering

Research (Activeness in offering the service)

Prototype design and development service (Activeness in offering the service)

Feasibility studies (Activeness in offering the service)

Problem analyses (Activeness in offering the service)

Analyses of a product's manufacturability (Activeness in offering the service)

Customer services

Product demonstrations (Activeness in offering the service)

Customer seminars (Activeness in offering the service)

Technical user training (Activeness in offering the service)

Written information material (Activeness in offering the service)

Customer consulting and support by phone (Activeness in offering the service)

Network capabilities

7-point Likert scales ranging from "fully disagree" to "fully agree" ( 1 = fully disagree, 7 = fully agree)

Coordination

We analyze what we would like to achieve with each partner

We remain informed about the goals, potential and strategies of our partners We determine in advance possible partners with whom to discuss the building of relationships

We appoint coordinators who are responsible for the relationships with our partners We regularly discuss with our partners how we can support one another in our success

Relational skills

We have the ability to build good personal relationships with business partners

We can imagine ourselves in our partners' position

We can act flexibly with our partners

We always solve problems that arise together with our partners in a constructive spirit

Partner knowledge

We know our partners' markets

We know our partners' products/working procedures/services

We know our partners' strengths and weaknesses

Internal communication

In our organization, employees develop informal contacts among themselves In our organization, communication is common across projects and subject areas

Sales growth

Sales growth rate 2008-2011 (Objective measure)

Control variables

Number of patents

Breadth of customer base (Number of customers)

Product performance (Product share of revenue)

Slack resources (Current ratio) 


\section{References}

Aiken, L. S., \& West, S. G. (1991). Multiple regression: Testing and interpreting interactions. Thousand Oaks: Sage.

Anderson, J., \& Gerbing, D. (1991). Predicting the performance of measures in a confirmatory factor analysis with a pretest assessment of their substantive validities. Journal of Applied Psychology, 76(5), 732-740.

Anderson, J. C., \& Narks, J. A. (1995). Capturing the value of supplementary services. Harvard Business Review, 73(1), 75-83.

Antioco, M., Moenaert, R. K., Feinberg, R. A., \& Wetzels, M. G. M. (2008a). Integrating service and design: The influences of organizational and communication factors on relative product and service characteristics. Journal of the Academy of Marketing Science, 36(4), 501-521.

Antioco, M., Moenaert, R. K., Lindgreen, A., \& Wetzels, M. G. M. (2008b). Organizationa antecedents to and consequences of service business orientations in manufacturing companies. Journal of the Academy of Marketing Science, 36(3), 337-358.

Baines, T., Lightfoot, H., Benedettini, O., \& Kay, J. (2009). The servitization of manufacturing: A review of literature and reflection on future challenges. Journal of Manufacturing Technology Management, 20(5), 547-567.

Baines, T. S., Lightfoot, H. W., \& Smart, P. (2011). Servitization within manufacturing: Exploring the provision af advanced services and their impact on vertical integration. Journal of Manufacturing Technology Management, 22(7), 947-954.

Ballantyne, D. (2004). Dialogue and its role in the development of relationship specific knowledge. The Journal of Business and Industrial Marketing, 19(2), 114-123.

Ballantyne, D., Williams, J., \& Aitken, R. (2011). Introduction to service-dominant logic: From propositions to practice. Industrial Marketing Management, 40(2), 179-180.

Baraldi, E., Gregori, G. L., \& Perna, A. (2011). Network evolution and the embedding of complex technical solutions: The case of the Leaf House network. Industrial Marketing Management, 40(6), 838-852.

Barney, J. B., Ketchen, D. J., \& Wright, M. (2011). The future of resource-based theory: Revitalization or decline? Journal of Management, 37(5), 1299-1315.

Baruch, Y. (1999). Response rates in academic studies: A comparative analysis. Human Relations, 52(4), 421-438.

Berghman, L., Matthyssens, P., \& Vandenbempt, K. (2006). Building competences for new customer value creation: An exploratory study. Industrial Marketing Management 35(8), 961-973.

Bollen, K. A. (1989). Structural equations with latent variables. New York: John Wiley \& Sons

Boyt, T., \& Harvey, M. (1997). Classification of industrial services: A model with strategic implications. Industrial Marketing Management, 26(4), 291-300.

Brady, T., Davies, A., \& Gann, D.M. (2005). Creating value by delivering integrated solutions. International Journal of Project Management, 23(5), 360-365.

Brambor, T., Clark, W., \& Golder, M. (2006). Understanding interaction models: Improving empirical analyses. Political Analysis, 14(1), 63-82.

Brislin, R. W. (1970). Back-translation for cross-cultural research. Journal of Cross-Cultura Psychology, 1(3), 185-216.

Byrne, B. (2001). Structural equation modeling with AMOS: Basic concepts, applications, and programming. London: LEA

Capaldo, A. (2007). Network structure and innovation: The leveraging of a dual network as a distinctive relational capability. Strategic Management Journal, 28(6), 585-608.

Carbonell, P., Rodríguez-Escudero, A. I., \& Pujari, D. (2009). Customer involvement in new service development: An examination of antecedents and outcomes. Journal of Product Innovation Management, 26(5), 536-550.

Cunningham, M. T., \& Roberts, D. A. (1974). The role of customer service in industrial marketing. European Journal of Marketing, 8(1), 15-28.

Davies, A. (2004). Moving base into high-value integrated solutions: A value stream approach. Industrial and Corporate Change, 13(5), 727-756.

Davies, A., Brady, T., \& Hobday, M. (2006). Charting a path toward integrated solutions. MIT Sloan Management Review, 47(3), 39-48

Davies, A., Brady, T., \& Hobday, M. (2007). Organizing for solutions: Systems seller vs. systems integrator. Industrial Marketing Management, 36(2), 183-193.

Davis, L. (1992). Instrument review: Getting the most from a panel of experts. Applied Nursing Research, 5(4), 194-197.

Dyer, J., \& Hatch, N. (2006). Relation-specific capabilities and barriers to knowledge transfers: Creating advantage through network relationships. Strategic Management Journal, 27(8), 701-719.

Fang, E., Palmatier, R. W., \& Steenkamp, J. -B. B. E. M. (2008). Effect of service transition strategies on firm value. Journal of Marketing, 72(5), 1-14.

Ford, D. (2011). IMP and service-dominant logic: Divergence, convergence and development. Industrial Marketing Management, 40(2), 231-239.

Gebauer, H. (2008). Identifying service strategies in product manufacturing companies by exploring environment-strategy configurations. Industrial Marketing Management 37(3), 278-291.

Gebauer, H., Edvardsson, B., \& Bjurko, M. (2010). The impact of service orientation in corporate culture on business performance in manufacturing companies. Journal of Service Management, 21(2), 237-259.

Gebauer, H., Edvardsson, B., Gustafsson, A., \& Witell, L. (2010). Match or mismatch: Strategy-structure configurations in the service business of manufacturing companies. Journal of Service Research, 13(2), 198-215.

Gebauer, H., Fischer, T., \& Fleisch, E. (2010). Exploring the interrelationship among patterns of service strategy changes and organizational design elements. Journal of Service Management, 21(1), 103-129.

Gebauer, H., \& Fleisch, E. (2007). An investigation of the relationship between behavioral processes, motivation, investments in the service business and service revenue. Industrial Marketing Management, 36(3), 337-348.

Gebauer, H., \& Friedli, T. (2005). Behavioral implications of the transition process from products to services. The Journal of Business and Industrial Marketing, 20(2), 70-78.
Gebauer, H., Ren, G. -J., Valtakoski, A., Reynoso, J., Guang-Jie, R., \& Reynose, J. (2012). Service-driven manufacturing: provision, evolution and financial impact of services in industrial firms. Journal of Service Management, 23(1), 120-136.

Gefen, D., Straub, D., \& Boudreau, M. -C. (2000). Structural equation modeling techniques and regression: Guidelines for research practice. Communications of AIS, 4(7), 2-77.

Grönroos, C. (2011). A service perspective on business relationships: The value creation, interaction and marketing interface. Industrial Marketing Management, 40(2), 240-247.

Harman, H. H. (1967). Modern Factor Analysis. Chicago: University of Chicago Press.

Harvey, C., Kelly, A., Morris, H., \& Rowlinson, M. (2010). Academic journal quality guide. London: The association of business schools.

Helander, A., \& Möller, K. (2007). System supplier's customer strategy. Industrial Marketing Management, 36(6), 719-730.

Helander, A., \& Möller, K. (2008). How to become solution provider: System supplier's strategic tools. Journal of Business-to-Business Marketing, 15(3), 247-287.

Homburg, C., Fassnacht, M., \& Guenther, C. (2003). The role of soft factors in implementing a service-oriented strategy in industrial marketing companies. Journal of Businessto-Business Marketing, 10(2), 23-51.

Homburg, C., Hoyer, W. D., \& Fassnacht, M. (2002). Service orientation of a retailer's business strategy: Dimensions, antecedents, and performance outcomes. Journal of Marketing, 66(4), 86-101

Hu, L., \& Bentler, P.M. (1999). Cutoff criteria for fit indexes in covariance structure analysis: Conventional criteria versus new alternatives. Structural Equation Modeling: A Multidisciplinary Journal, 6(1), 1-55.

Jacob, F., \& Ulaga, W. (2008). The transition from product to service in business markets: An agenda for academic inquiry. Industrial Marketing Management, 37(3), 247-253.

Jiang, Z., Henneberg, S.C., \& Naudé, P. (2011). The importance of trust vis-à-vis reliance in business relationships: Some international findings. International Marketing Review, 28(4), 318-339.

Kale, P., Dyer, J., \& Singh, H. (2002). Alliance capability, stock market response, and long term alliance success: The role of the alliance function. Strategic Management Journal, 23(8), 747-767.

Kale, P., Singh, H., \& Arbor, A. (2007). Building firm capabilities through learning: The role of the alliance learning process in alliance capability and firm-level alliance success. Strategic Management Journal, 28(10), 981-1000.

Kandemir, D., Attila, Y., \& Cavusgil, S. T. (2006). Alliance orientation: Conceptualization, measurement, and impact on market performance. Journal of the Academy of Marketing Science, 34(3), 324-340.

Kim, H. -S., \& Kim, Y. -G. (2009). A CRM performance measurement framework: Its development process and application. Industrial Marketing Management, 38(4), 477-489.

Kohtamäki, M., Partanen, J., \& Möller, K. (2013). Making a profit with R\&D services-The critical role of relational capital. Industrial Marketing Management, 42(1), 71-81.

Kowalkowski, C., Witell, L., \& Gustafsson, A. (2013). Any way goes: Identifying value constellations for service infusion in SMEs. Industrial Marketing Management, 42(1), 18-30.

LaLonde, B. J., \& Zinszer, P. H. (1976). Customer service meaning and measurement. Chicago: National Council of Physical Distribution Management.

Lambe, C. J., Spekman, R. E., \& Hunt, S. D. (2002). Alliance competence, resources, and alliance success: Conceptualization, measurement, and initial test. Journal of the Academy of Marketing Science, 30(2), 141-158.

Leek, S., \& Christodoulides, G. (2012). A framework of brand value in B2B markets: The contributing role of functional and emotional components. Industrial Marketing Management, 41(1), 106-114.

Little, T. D., Cunningham, W. A., Shahar, G., \& Widaman, K. F. (2002). To parcel or not to parcel: Exploring the question, weighting the merits. Structural Equation Modeling, 9(2), 151-173

Lockett, H., Johnson, M., Evans, S., \& Bastl, M. (2011). Product-service systems and supply network relationships: An exploratory case study. Journal of Manufacturing Technology Management, 22(3), 293-313.

Löfberg, N., Witell, L., \& Gustafsson, A. (2010). Service strategies in a supply chain. Journal of Service Management, 21(4), 427-440.

Long, C., \& Vickers-Koch, M. (1995). Using core capabilities to create competitive advantage. Organizational Dynamics, 24(1), 7-22.

Lovelock, C., \& Wirtz, J. (2007). Services marketing: People, technology, strategy. Upper Saddle River, New York: Pearson Prentice Hall.

Lusch, R., Vargo, S., \& Tanniru, M. (2010). Service, value networks and learning. Journal of the Academy of Marketing Science, 38(1), 19-31.

Madhok, A., \& Tallman, S. B. (1998). Resources, transactions and rents: Managing value through interfirm collaborative relationships. Organization Science, 9(3), 326-339.

Mathieu, V. (2001). Service strategies within the manufacturing sector: Benefits, costs and partnership. International Journal of Service Industry Management, 12(5), 451-475.

Matthyssens, P., \& Vandenbempt, K. (2008). Moving from basic offerings to value-added solutions: Strategies, barriers and alignment. Industrial Marketing Management, 37(3), 316-328.

Meier, H., Völker, O., \& Funke, B. (2011). Industrial product-service system (IPS ${ }^{2}$ ): Paradigm shift by mutually determined products and services. International Journal of Advance Manufacturing Technology, 59(9-12), 1175-1191.

Mintzberg, H., \& Lampel, J. (1999). Reflecting on the strategy process. Sloan Management Review, 40(3), 21-30.

Möller, K., Rajala, R., \& Westerlund, M. (2008). Service innovation myopia? A new recipe for client-provider value-creation. California Management Review, 50(3), 31-48.

Möller, K., \& Törrönen, P. (2003). Business suppliers' value creation potential: A capability-based analysis. Industrial Marketing Management, 32(2), 109-118.

Moore, G. (1995). Crossing the chasm: Marketing and selling high-tech products to mainstream customers. New York: Harper Collins Publishers.

Morris, M. H., \& Davis, D. L. (1992). Measuring and managing customer service in industrial firms. Industrial Marketing Management, 21(4), 343-353. 
Nam, K., \& Lee, N. (2010). Typology of service innovation from service-dominant logic perspective. Journal of Universal Computer Science, 16(3), 1761-1775.

Neely, A. (2008). Exploring the financial consequences of the servitization of manufacturing. Operations Management Research, 1(2), 103-118.

Neu, W. A., \& Brown, S. W. (2005). Forming successful business-to-business services in goods-dominant firms. Journal of Service Research, 8(3), 3-17.

Oliva, R., \& Kallenberg, R. (2003). Managing the transition from products to services. International Journal of Service Industry Management, 14(2), 160-172.

Orr, L. M., Bush, V. D., \& Vorhies, D. W. (2011). Leveraging firm-level marketing capabilities with marketing employee development. Journal of Business Research, 64(10), 1074-1081.

Paulraj, A., Lado, A. A., \& Chen, I. J. (2008). Inter-organizational communication as a relational competency: Antecedents and performance outcomes in collaborative buyersupplier relationships. Journal of Operations Management, 26(1), 45-64.

Payne, A. F., Storbacka, K., \& Frow, P. (2008). Managing the co-creation of value. Journal of the Academy of Marketing Science, 36(1), 83-96.

Phan, M. C. T., Styles, C. W., \& Patterson, P. G. (2005). Relational competency's role in Southeast Asia business partnerships. Journal of Business Research, 58(2), 173-184.

Podsakoff, P. M., \& Organ, D. W. (1986). Self-Reports in organizational research: Problems and prospects. Journal of Management, 12(4), 531-544.

Podsakoff, P.M., MacKenzie, S. B., Lee, J. -Y., \& Podsakoff, N.P. (2003). Common method biases in behavioral research: A critical review of the literature and recommended remedies. Journal of Applied Psychology, 88(5), 879-903.

Polit, D. F., Beck, C. T., \& Owen, S. V. (2007). Focus on research methods: Is the CVI an acceptable indicator of content validity? Research in Nursing E Health, 30(4), 459-467.

Raddats, C. (2011). Aligning industrial services with strategies and sources of market differentiation. The Journal of Business and Industrial Marketing, 26(5), 332-343.

Raddats, C., \& Burton, J. (2011). Strategy and structure configurations for services within product-centric businesses. Journal of Service Management, 22(4), 522-539.

Raddats, C., \& Easingwood, C. (2010). Services growth options for B2B product-centric businesses. Industrial Marketing Management, 39(8), 1334-1345.

Ramirez, R. (1999). Value co-production: intellectual origins and implications for practice and research. Strategic Management Journal, 20(1), 49-65.

Ritter, T., \& Gemünden, H. G. (2003). Network competence: Its impact on innovation success and its antecedents. Journal of Business Research, 56(9), 745-755.

Ritter, T., \& Gemünden, H. G. (2004). The impact of a company's business strategy on its technological competence, network competence and innovation success. Journal of Business Research, 57(5), 548-556.

Rönkkö, M., \& Ylitalo, J. (2011). An approach to control method variance in PLS: Development and Monte Carlo analysis. Espoo, Finland: Aalto University.

Salonen, A. (2011). Service transition strategies of industrial manufacturers. Industrial Marketing Management, 40(5), 683-690.

Samli, C. A., Jacobs, L. W., \& Wills, J. (1992). What presale and postsale services do you need to be competitive? Industrial Marketing Management, 21(1), 33-41.

Schreiner, M., Kale, P., \& Corsten, D. (2009). What really is alliance management capability and how does it impact alliance outcomes and success? Strategic Management Journal, 30(13), 1395-1419.

Smirnova, M., Naudé, P., Henneberg, S.C., Mouzas, S., \& Kouchtch, S. P. (2011). The impact of market orientation on the development of relational capabilities and performance outcomes: The case of Russian industrial firms. Industrial Marketing Management, 40(1), 44-53.

Swaminathan, V., \& Moorman, C. (2009). Marketing alliances, firm networks, and firm value creation. Journal of Marketing, 73(5), 52-69.

Tabachnick, B. G., \& Fidell, L. S. (2007). Using multivariate statistics. Boston: Pearson.

Theoharakis, V., Sajtos, L., \& Hooley, G. (2009). The strategic role of relational capabilities in the business-to-business service profit chain. Industrial Marketing Management, 38(8), 914-924

Tukker, A. (2004). Eight types of product-service system: Eight ways to sustainability? Experiences from Suspronet. Business Strategy and the Environment, 13(4), 246-260.

Ulaga, W., \& Reinartz, W. J. (2011). How manufacturing firms combine goods and services successfully. Journal of Marketing, 75(November), 5-23.
Uppenberg, K., \& Strauss, H. (2010). Innovation and productivity growth in the EU services sector. Luxembourg: European Investment Bank.

Vargo, S. L., Maglio, P. P., \& Akaka, M.A. (2008). On value and value co-creation: A service systems and service logic perspective. European Management Journal, 26(3), 145-152.

Visnjic, I., Neely, A., \& Wiengarten, F. (2012). Another performance paradox? A refined view on the performance impact of servitization. Working paper. Cambridge: University of Cambridge.

Wales, J. W., Patel, C. P., Parida, V., \& Kreiser, P. M. (n.d.). Non-linear effects of entrepreneurial orientation on small firm performance: The moderating role of resource orchestration capabilities. Strategic Entrepreneurship Journal.

Walter, A., Auer, M., \& Ritter, T. (2006). The impact of network capabilities and entrepreneurial orientation on university spin-off performance. Journal of Business Venturing 21(4), 541-567.

Walter, A., Ritter, T., \& Gemüden, H. G. (2001). Value creation in buyer-seller relationships. Industrial Marketing Management, 30(4), 365-377.

Westerberg, M., Singh, J., \& Häckner, E. (1997). Does the CEO matter? An empirical study of small Swedish firms operating in turbulent environments. Scandinavian Journal of Management, 13(3), 251-270.

Windahl, C., \& Lakemond, N. (2006). Developing integrated solutions: The importance of relationships within the network. Industrial Marketing Management, 35(7), 806-818

Windahl, C \& Lakemond, N. (2010). Integrated solutions from a service-centered perspective: Applicability and limitations in the capital goods industry. Industrial Marketing Management, 39(8), 1278-1290.

Wittmann, C. M., Hunt, S. D., \& Arnett, D. B. (2009). Explaining alliance success: Competences, resources, relational factors, and resource-advantage theory. Industrial Marketing Management, 38(7), 743-756.

Wynstra, F., Van Weele, A., \& Weggemann, M. (2001). Managing supplier involvement in product development: Three critical issues. European Management Journal, 19(2), 157-167.

Marko Kohtamäki is a Professor in research group of "Networked Value Systems" at the University of Vaasa. He takes special interest in industrial services, business networks and strategy work of technology companies. He has published in journals such as Industrial Marketing Management, Strategic Entrepreneurship Journal and Journal of Business and Industrial Marketing.

Jukka Partanen, Ph.D. (Econ), is a postdoctoral researcher at Aalto University, School of Economics (Department of Marketing). His work has been published in such journals as Entrepreneurship Theory and Practice and Industrial Marketing Management. His research interests include strategic networks and alliances, SME networks, high-growth firms, industrial service business and innovation.

Vinit Parida is assistant professor of Entrepreneurship and Innovation at Luleå University of Technology. He received his Ph.D. on the topic on achieving competitiveness through externally oriented capabilities from the same university. His research interests are the capabilities-based view, entrepreneurship, open innovation and $\mathrm{R} \& \mathrm{D}$ offshore collaboration. He has published in the Journal of Small Business Management, Strategic Management Journal, Strategic Entrepreneurship Journal, Production and Operations Management, International Journal of technology and Marketing and other journals and anthologies in the area of entrepreneurship and management

Joakim Wincent is Professor of Entrepreneurship and Innovation at Luleå University of Technology, Sweden. His current research focuses largely on strategic interorganizational relationships, open innovation, competition, emotion and stress management in innovative processes. He has published in journals such as Academy of Management Review, Journal of Management Studies, British Journal of Management, Journal of Business \& Psychology, Journal of Business Research, Long Range Planning, Group \& Organization Management, Organizational Research Methods and Scandinavian Journal of Management. 